\title{
A OBRA DE ARTE EM MARTIN HEIDEGGER
}

\author{
Ana Catharina Marques ${ }^{1}$
}

Resumo: A dificuldade em entender o estudo de Martin Heidegger sobre A Origem da Obra de Arte não está apenas na complexidade do tema em questão e conceitos, mas também na incapacidade da linguagem em expressar o que se apreende e se vivencia como obra de arte. Além disso, os termos utilizados por ele possuem sentidos diferentes do que estamos acostumados, os significados para ele estão sempre em aberto e recebem a todo o momento questionamentos, no intuito de testar a concretude do que esta sendo elaborado. Para ordenar o estudo sobre a questão da obra de arte, se faz necessário tomar o caminho que tem como princípio fundamental o entendimento do sentido de origem, do SER e do ENTE.

\section{Obra de Arte}

A questão de Heidegger sobre a Obra de Arte é a questão da origem da obra. Conhecer o que é essa origem e como ela acontece, enquanto proveniência da sua essência é a maneira para apreender a obra de arte. Na busca pelo entendimento dessa origem fundamental ele caminha, no livro, por três dualidades: A coisa e a obra, A obra e a verdade, $A$ verdade e a arte.

Nessa separação, ele sai do imediato e simples, 'a coisa' e vai em busca do foco do estudo, da questão sobre 'a arte'. Para ele a origem é a própria arte. “Origem significa aqui aquilo a partir do qual e através do qual uma coisa é o que é, como é."2. Para descobrir a origem tem-se que estar na arte.

Heidegger questiona sobre a origem da obra no artista, mas não coloca o artista como único em importância para a obra, mas pelo qual a obra nasce. A obra e o artista existem pelo interesse comum da arte. A arte é ao mesmo tempo a origem do artista e da obra, "[...] a obra é que primeiro faz aparecer o artista como um mestre da arte. $\mathrm{O}$ artista é a origem da obra. A Obra é a origem do artista. Nenhum é sem o outro." ${ }^{3}$ Desse entendimento surge a questão, se a arte pode ser a origem já que a palavra arte não corresponde a nada de real, palpável. Entretanto Heidegger identifica que a arte não corresponde a uma palavra, ou a uma única realidade, mas é formada por duas coisas reais: o artista e a obra de arte. Heidegger percorre nesses extremos, artista e obra de arte, o caminho da existência, da materialidade da arte, da feitura da obra até o seu reconhecimento, até a apreensão da verdade na obra.

\footnotetext{
${ }^{1}$ Mestranda FAU - UnB.

${ }^{2}$ HEIDEGGER, Martin. A Origem da Obra de Arte. Tradução: Maria da Conceição Costa. Lisboa, Portugal: Edições 70, Ltda. 2005, p 11.

${ }^{3}$ Idem, Ibidem, p. 11.

REVISTA DE ESTÉTICA E SEMIOTICA, BRASÍLIA, V. 2, N. 1 P. 1-15, JAN./JUN. 2012.
} 
A coisa, a obra e a verdade chamam atenção por ser o meio, por ser o caminho a percorrer e ser a parte em que a coisa não é mais um mero utensílio e sim, uma obra; ainda, por ser a parte que tenta entender como a verdade é e está na obra. "O que a arte seja, tem de apreender-se a partir da obra. O que seja a obra, só o podemos experienciar a partir da essência da arte. Qualquer um nota com facilidade que nos movemos em círculos"4. Heidegger afirma que não se pode avaliar uma obra de arte por processo comparativo a outra obra, pois assim, não se sabe o que é arte, mas apenas uma comparação entre elementos previamente intitulados que ele chama de coisa (em alemão: Dinhaft). É nesse momento que ele abre o questionamento sobre a coisa e insere o conceito de "coisalidade da obra" . "Se considerarmos na obra a sua pura realidade, sem nos deixarmos influenciar por nenhum preconceito, torna-se evidente que as obras estão presentes de modo tão natural como as demais coisas. [...] Todas as obras tem esse caráter de coisa (das Dinhaft)"

É necessário para Heidegger, agora, discorre sobre a coisa e a obra. Surge a questão sobre a coisa. Para ele, a obra não é só coisa, mas também não é só vivencia, apreciação e experiência estética. Para ele a obra é coisa ao ponto de considerarmos que um utensílio, ou um troço (em alemão: Zeug) pode ter um sentido para além da sua mera utilidade. A obra é algo de outro, que vai além da coisa e é onde se constitui o artístico. Assim, "a obra de arte é, com efeito, uma coisa, uma coisa fabricada, mas ela diz ainda algo diferente do que a simples coisa é"7. Assim, a arte é alegoria no sentido de publicar uma outra coisa que não apenas si mesma e é símbolo ao representar em um, ambos (a própria coisa e o outro). Essa unidade é, para Heidegger, o caráter de coisa da obra.

\section{A coisa}

Heidegger coloca três questionamentos para que se possa entender a coisa e com isso o caráter de coisa da obra.

1 - Uma simples coisa: um bloco de granito com suas características. Mas as características não são a coisa. A coisa as tem. Sendo assim: “A coisa é como todos

\footnotetext{
${ }^{4}$ Idem, op. cit., p. 12.

${ }^{5}$ Idem, op. cit., p. 13.

${ }^{6}$ Idem, op. cit., p. 13.

${ }^{7}$ Idem, op. cit., p. 13.

REVISTA DE ESTÉTICA E SEMIOTICA, BRASÍLIA, V. 2, N. 1 P. 1-15, JAN./JUN. 2012.
} 


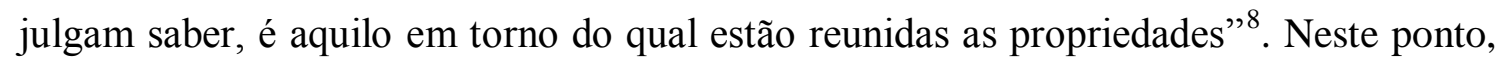
Heidegger começa a questionar a estrutura sintática com que a língua permite explicar a coisa: sujeito e predicado. Ele sugere que talvez precisasse existir outra estrutura, que não a de causa e efeito, colocando sempre a coisa com seu predicado, pois não se percebem ambos separadamente: a percepção é única. Não há um primeiro para depois um segundo. É a fonte comum mais original, a coisa como suporte de suas características. Para ele, as explicações que se dá à coisa, ou como se as reconhece, vêm de um sistema que impede a visualização da coisa em si, do reconhecimento do que é a coisa. Como se ela fosse determinada antes de a conhecermos

2 - Um meio para se apreender a coisa, seria deixar o campo dela livre para que ela possa se mostrar, revelar seu caráter. Neste ponto, as percepções tomam conta do entendimento e a coisa em si também desaparece. Deve-se distanciar e afastar de tudo que foi dito e entendido previamente sobre a coisa (sem a coisa em si):

Tudo o que se queira entrepor entre nós e a coisa como
concepção e enunciado sobre a coisa deve ser afastado. Só
então poderemos abandonar-nos a presença não mascarada da
coisa. Mas esse imediato ir ao encontro das coisas, não temos
de o provocar, ou mesmo de organizar. Há muito ele produz.
[...] A coisa é o que é perceptível nos sentidos da sensibilidade,
através das sensações. Por conseguinte, tornou-se habitual,
mais tarde, o conceito de coisa, segundo o qual ela nada mais é
do que a unidade de uma multiplicidade do dado nos sentidos.
Que esta unidade seja concebida como soma, totalidade, ou
forma em nada altera o traço fundamental desse conceito. ${ }^{9}$

3 - A coisa em si, nuclearidade. Nosso reconhecimento da coisa por ela ter uma forma. Essa terceira definição sintetiza a matéria e a forma nos colocando ao encontro do real conceito da coisa. A coisa é a matéria em uma forma (terceira definição), "A coisa é uma matéria enformada. [...] O caráter coisal da obra é manifestamente, a matéria é o suporte e o campo para a informação artística" ${ }^{\prime 10}$. Entretanto, para Heidegger esse conceito também carrega uma desconfiança, apesar desse esquema ser o conceito de toda estética e teoria das artes. Ainda, forma e conteúdo pertencem a tudo, e tudo se cabe nesse conceito. Entretanto, onde o complexo matéria e forma têm sua origem? Heidegger pergunta se é no caráter coisal da coisa ou no caráter de obra da obra de arte. Daí ele passa a definir Forma e matéria. Forma é vista como uma matéria com um

\footnotetext{
${ }^{8}$ Idem, op. cit., p. 16 .

${ }^{9}$ Idem, op. cit., p. 18.

${ }^{10}$ Idem, op. cit., p. 19.

REVISTA DE ESTÉTICA E SEMIOTICA, BRASÍLIA, V. 2, N. 1 P. 1-15, JAN./JUN. 2012.
} 
determinado contorno. "A forma determina pelo contrário, a ordenação da matéria" 11 . Desse modo, a forma e matéria definem a finalidade da coisa: matéria mais forma mais finalidade. Por essa serventia é que se define a forma e a matéria. Heidegger entra agora com o conceito de utensílio, troço (Zeug), o que é fabricado pela mão do homem para ser utilizado e usado (diferente de um bloco de pedra). A semelhança que existe entre o utensílio e a obra de arte, seria a sua fabricação pelo homem, e não pela natureza como acontece com o bloco de pedra. Mas o utensílio não é auto suficiente como a obra. Por isso matéria e forma não são determinações originais da coisidade da coisa. O utensílio estaria entre a coisa e a obra. Algo mais que a coisa, e menos que a obra. "Neste sentido o utensílio é meio coisa, portanto determinado pela coisidade e, todavia mais; ao mesmo tempo é meio obra de arte e, todavia, menos porque não tem a auto-suficiência da obra de $\operatorname{arte}{ }^{12}$.

Os três pensamentos acerca a coisa são expostos e questionados e nenhuma satisfaz o entendimento da coisa. Elas concebem a coisa como um "suporte de características, como a unidade de uma multiplicidade de sensações, como matéria enformada"13. Esses meios antecipam o conceito de coisa e por isso acaba afastando o homem da identificação da própria coisa, e assim, barra o caminho para o caráter da coisa, do utensílio e da obra. Caráter é o que é a essência, a verdade. Sendo assim, todas as explicações acima e seus questionamentos nos levam a um lugar direcionado por Heidegger que é voltarmos para pensar o ENTE, pensá-lo em si mesmo, no seu SER e com isso, reconhecer a sua essência.

Para tanto e afastando-nos um pouco das três interpretações imediatistas citadas acima, Heidegger torna prática suas explicações sobre a coisa e descreve livremente o utensílio (sem teorias filosóficas) um sapato de camponês do quadro de Van Gogh como "presentificacao intuitiva"14 (em alemao: Veranschaulichung).

\footnotetext{
${ }^{11}$ Idem, op. cit., p. 20.

${ }^{12}$ Idem, op. cit., p. 21.

${ }^{13}$ Idem, op. cit., p. 23.

${ }^{14}$ Idem, op. cit., p. 24.

REVISTA DE ESTÉTICA E SEMIOTICA, BRASÍLIA, V. 2, N. 1 P. 1-15, JAN./JUN. 2012.
} 


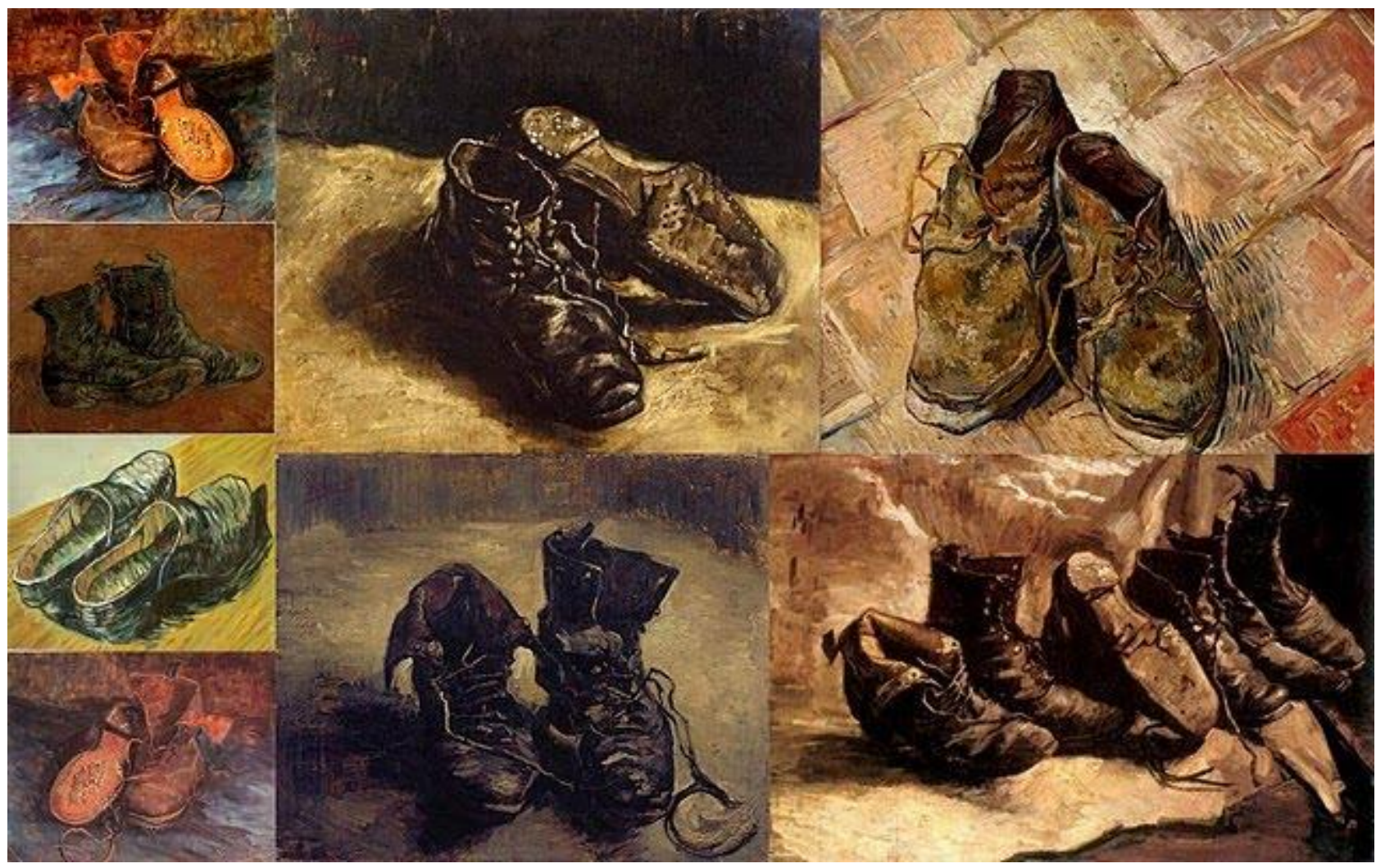

Coletânea das imagens de sapatos de camponês pintados por Van Gogh.

“[...] Um utensílio deste tipo serve para calcar os pés. Consoante a serventia, se para o trabalho no campo, ou para dançar, assim diferem matéria e forma" ${ }^{15}$. Aqui só está explicado a serventia do objeto, quando o "SER-utensílio repousa na sua serventia" 16 . O sapato de camponês pictórico não tem presente em si sua serventia, esta ali, como se estivesse em qualquer lugar e não se pode apreender seu caráter instrumental. É apenas "um par de sapatos de camponês e nada mais" "17. A partir disso, já que não se pode apreender utilidades concretas, pra Heidegger é necessário aprender o sentido do que está ali desenhado. Puramente pelos elementos, observamos o que eles representam e o que querem revelar.

$\mathrm{Na}$ escura abertura do interior gasto dos sapatos, fita-nos a dificuldade e o cansaço dos passos do trabalhador. $\mathrm{Na}$ gravidade rude e sólida dos sapatos está retida a tenacidade do lento caminhar pelos sulcos que se estendem até longe, sempre iguais, pelo campo, sobre o qual sopra um vento agreste. No couro está a humildade e a fertilidade do solo. Sob as solas, insinua-se a solidão do caminho do campo, pela noite que cai. No utensílio para calcar impera o apelo calado da terra, a sua

\footnotetext{
${ }^{15}$ Idem, op. cit., p. 24.

${ }^{16}$ Idem, op. cit., p. 25.

${ }^{17}$ Idem, op. cit., p. 25.

REVISTA DE ESTÉTICA E SEMIOTICA, BRASÍLIA, V. 2, N. 1 P. 1-15, JAN./JUN. 2012.
} 
muda oferta do trigo que amadurece e a sua inexplicável recusa na desolada improdutividade do campo no inverno. Por este utensílio passa o calado temor pela segurança do pão, a silenciosa alegria de vencer uma vez mais a miséria, a angústia do nascimento iminente e o tremor ante a ameaça da morte. Este utensílio pertence à Terra e está abrigado no Mundo da camponesa. É a partir desta abrigada que o próprio produto surge para o seu repousar-em-si-mesmo. ${ }^{18}$

Heidegger faz uma análise sensorial dos elementos para si. Análise que, com certeza, está carregada do mundo pelo qual ele vive. Outro poderia, pela mesma imagem, apreender sensações diferentes, por pertencer a outro mundo. Entretanto, todos reconheceriam um sapato gasto, sofrido por ter sido usado abundantemente, independente do mundo de onde se tenha vindo. No trecho supracitado, Heidegger apresenta Mundo e Terra como conceitos que fazem parte do objeto analisado. Esses são conceitos instaurados por ele para ilustrar a relação entre o que no utensílio é matéria e o que é sentido. Aqui, Terra e o Mundo são a solidez (em alemão: Verlasslichkeit) do utensílio. Essa solidez trás a Terra (matéria) e mostra o Mundo (sentido). A solidez, o que ali é sólido e não se desfaz, permite a percepção além da serventia, permite que a Terra e o Mundo, onde todas as coisas se conjugam, sejam identificados a cada momento e a sua maneira com algo distinto. Aqui, Heidegger prepara o campo para a construção do complexo da obra. Uma construção intermitente, que não se fecha e que a cada momento revela a obra em partes, o que Heidegger chamará do combate entre Mundo e Terra. Esse movimento de combate sugerido retomado a frente para melhor entendimento.

O que está em questão agora é a definição da solidez. A serventia é a consequiência essencial da solidez ${ }^{19}$. O utensílio existe por ela, mas não termina nela. A solidez de que se fala seria a força do objeto em representar algo além da sua utilidade. Assim, um objeto que se perde pelo seu uso, possui uma solidez escassa; que maior será quanto mais se esquece o objeto em si pela sua utilidade. Seria o 'Mero utensílio' que é a fabricação de uma forma em uma matéria.

O sapato para a camponesa é apenas um sapato, objeto de serventia. Mas ele, no quadro, possui uma dimensão a mais. Ao olhar os sapatos no quadro de Van Gogh, e ao deixarmos a obra falar, descobrimos o "SER-utensílio do utensílio". "A obra de arte fez saber o que o utensílio de calcado na verdade é. [...] Antes sucede que só através da

\footnotetext{
${ }^{18}$ Idem, op. cit., p. 25.

${ }^{19}$ Idem, op. cit., p. 26.

REVISTA DE ESTÉTICA E SEMIOTICA, BRASÍLIA, V. 2, N. 1 P. 1-15, JAN./JUN. 2012.
} 
obra, e só nela, o SER-utensílio do utensílio vem expressamente a luz" ${ }^{20}$. Com essa compreensão, vê-se que não foi apenas uma questão intuitiva a análise do calcado, mas foi o que veio da obra, o que estava ali representado. E o que está ali representado, é o que já foi, em algum momento vivenciado, apreendido. Mas, o que realmente está ali representado que pode ser visto por todos, e que mantém a obra? "O que se passa aqui? Que é que está em obra na obra?

A pintura de Van Gogh constitui a abertura do que o utensílio, o par de sapatos da camponesa, na verdade é. Este ENTE emergente no desvelamento do seu SER. Ao

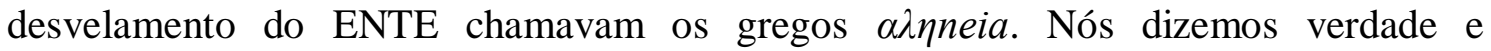
pensamos bastante pouco com essa palavra. Na obra, se nela acontece uma abertura do ENTE, no que é e no modo como é, está em obra um acontecer da verdade ${ }^{21}$. O significado da obra é sempre uma construção, que vai acontecendo a cada momento em que o ENTE se mostra. Só que esse significado não é único, e nem estático, é sempre uma construção e uma revelação. E essa revelação é a Verdade. O que o utensílio é além da sua utilidade. O que é num determinado momento. Na obra um ENTE emerge por estar na clareira do seu SER. Nessa linha Heidegger conclui que a essência da obra de arte seria então o "por-se-em-obra da verdade do ENTE (das sich-ins-werk-setzen der wahrheit des seienden)" ${ }^{22}$. Na história a obra não possuía compromisso com a verdade. Até então a obra de arte tinha compromisso apenas com o belo e a beleza (intuitivo/subjetivo em Kant).

\footnotetext{
As artes que produzem obras deste gênero, por oposição as artes de manufactura que fabricam utensílios, são chamadas belas artes. Nas belas artes não é a arte que é bela, chama-se assim porque produzem o belo. A verdade, pelo contrario, pertence à lógica. A beleza está reservada a estética. ${ }^{23}$
}

Agora a obra de arte não se trata de uma reprodução singular do ENTE, mas da reprodução da essência geral das coisas. Não é a cópia, pois não se copia o que é, mas é uma reprodução do que existe, com um sentido e uma expressividade determinada. Portanto, o que se tem é a tentativa de explicar o sentido da coisa na obra. A coisa como matéria enformada que provém da essência do utensílio. Esse SER-utensílio prevalece

\footnotetext{
${ }^{20}$ Idem, op. cit., p. 27.

${ }^{21}$ Idem, op. cit., p. 27.

${ }^{22}$ Idem, op. cit., p. 27.

${ }^{23}$ Idem, op. cit., p. 28.

REVISTA DE ESTÉTICA E SEMIOTICA, BRASÍLIA, V. 2, N. 1 P. 1-15, JAN./JUN. 2012.
} 
no ENTE. "Deixamos que fosse uma obra a dizer-nos quem um utensílio é" 24 . O que na obra esta em obra é a abertura do ENTE no seu SER, que seria o acontecimento da verdade. A obra não é utensílio com valor estético. Assim, como a mera coisa não é um utensílio sem seu caráter de serventia e de fabricação.

\begin{abstract}
A forma como ela (a estética)considera antecipadamente a obra de arte esta sobe o domínio da interpretação tradicional de todo o ENTE enquanto tal. (...)O que importa é uma primeira abertura do olhar para o facto de o caráter de obra, o caracter instrumental do utensílio, o elemento coisal da coisa, só se torna mais próximo de nós, se pensarmos o SER do ENTE. Para tal é necessário que caiam primeiro as barreiras do que é óbvio (das selbstverstandlich) e que os ilusórios conceitos habituais sejam postos de lado. ${ }^{25}$
\end{abstract}

O movimento de entendimento da coisa na obra é o caminho que nos leva a coisa através da obra, e não o inverso, pela coisa chegar à obra. É nesse movimento que na obra acontece a abertura do SER do ENTE, o desocultar, a verdade do ENTE.

\title{
A obra
}

A origem da obra de arte é a arte ${ }^{26}$, é assim que Heidegger afirma que a arte é o real na obra de arte e é por isso que antes de tudo procuramos a realidade da obra de arte, pois ela mostra sempre a coisalidade. "Na obra de arte, a verdade do ENTE pôs-se em obra na obra. A arte é o pôr-se-em-obra da verdade" ${ }^{27}$. Entendendo a coisa na obra e considerando que ao reconhecer a coisa acontece o desocultar do ente, enquanto verdade, vê-se que Heidegger considera que o processo de reconhecimento da obra é dado por uma construção, como se a obra e o entendimento dela fosse um aberto, e que a cada momento, nesse aberto, parte da obra se mostra, e naquele momento o que está a mostra é uma verdade.

Não só a coisa é importante para o reconhecimento da obra, o artista também é um elemento responsável pela existência da obra. Heidegger considera o artista como algo indiferente da obra depois dela realizada. Para ele o artista é o acesso á obra. Ele é o que anula a si próprio para o surgimento da obra. É como se o SER da obra fosse

\footnotetext{
${ }^{24}$ Idem, op. cit., p. 29.

${ }^{25}$ Idem, op. cit., p. 30.

${ }^{26}$ Idem, op. cit., p. 31.

${ }^{27}$ Idem, op. cit., p. 30.

REVISTA DE ESTÉTICA E SEMIOTICA, BRASÍLIA, V. 2, N. 1 P. 1-15, JAN./JUN. 2012.
} 
realizado por ele, mas não pertencesse a ele e sim, a própria obra. É aonde a obra vem a SER.

Para ser materializada, mundificada a obra precisa do artista. É por ele que a arte fala e surge a obra. Mas depois de acabada e instaurada, a obra é por ela mesma um SER. E o artista passa a não mais fazer parte. A obra agora é autônoma. Sendo assim, a obra não é obra por que foi produzida por um artista, mas pelo artista através da arte, criar uma obra. Isso significa que nem sempre o artista, será artista na polução de um utensílio, pois não é a determinação de artista que gera a obra. Considerando que o artista é o meio pelo qual a arte é realizada, Heidegger questiona as obras que se encontram penduradas em exposições que em sua maioria talvez estejam ali pelo nome do artista. Por isso a crítica de Heidegger a dinâmica atual do mundo da arte é dura. Para ele as obras que aí estão ruíram. "Mas estarão elas porventura aqui em si próprias, como as obras que elas mesmas são, ou estarão antes aqui como objeto do funcionamento das coisas no mundo da arte (em alemão: kunstbetrieb)?" ${ }^{28} \mathrm{Na}$ visão dele, não existe o ressurgimento de uma obra que ruiu, que já acabou, o que permanece agora será um mero objeto. A obra não pode ser refeita, existe apenas uma vez e permanece.

Entretanto, como uma obra ruiria? Se a obra permanece ela não rui. O que se entende aqui não é a ruína de uma obra, mas o considerar obra o que não é obra; o reconhecer de uma obra que não é obra. Heidegger coloca em questão essa valorização do artista além da obra. Como se o Artista fosse a origem da obra. Aí, claro, quando se coloca a prova essa inverdade da obra considerada, vê-se que não é a própria obra. Então, não seria uma ruína da obra que ali está, mas a descoberta de uma não-obra. Não sendo obra, não poderia permanecer. A obra, quando existe estabelece um mundo de sentidos e expressões que são vivenciados apenas através da obra. É nesse mundo que a obra permanece, é onde ela está e é. Nesse momento, enquanto a obra é obra sua verdade se constitui e é montada, construída, a cada momento e instante na qual ela é apreendida. Assim ela permanece. "A obra permanece enquanto obra ao campo que é aberto por ela própria. Porque o SER-obra da obra advém, em tal abertura. Dissemos que, na obra, o acontecimento da verdade estava em obra” ${ }^{\text {} 29}$.

A obra posta em vista, publicada, apresentada está instalada. A obra exige sua instalação por ser uma "instaladora". Ela abre um Mundo, instala algo que domina. A

\footnotetext{
${ }^{28}$ Idem, op. cit., p. 31.

${ }^{29}$ Idem, op. cit., p. 32.

REVISTA DE ESTÉTICA E SEMIOTICA, BRASÍLIA, V. 2, N. 1 P. 1-15, JAN./JUN. 2012.
} 
instalação consagra e glorifica a obra. Para Heidegger consagrar significa erigir pela obra o sagrado, o Deus, e glorificar significa respeito pela dignidade e esplendor de Deus. Sendo assim, Heidegger utiliza os termos Terra e Mundo (diferente da maneira que estamos costumados a utilizar) para explicar o processo de reconhecimento, de visualização da obra. O que a obra de arte representa é visto, e é permitido ser visto através dessa Terra. O que é visto, percebido é a instauração de um Mundo. "A obra que é o templo, ali de pé, abre um Mundo e ao mesmo tempo repoe-no sobre a Terra que, só então, vem a luz como o solo pátrio (heimatlich grund)" ${ }^{\text {30 }}$. A obra de arte está ali, colocando-se á vista. Essa vista esta aberta enquanto a obra for obra (construção) para quem vê. Não se trata de uma representação, mas do vir a ser o próprio significado que a obra é.

\footnotetext{
SER obra significa instalar um Mundo. (...)Mundo não é simplesmente reunião das coisas existentes, contáveis ou incontáveis, conhecidas ou desconhecidas. Mas mundo também não é uma moldura meramente imaginada, representada em acréscimo a soma das coisas existentes. $\mathrm{O}$ mundo mundifica (welt weltet) e é algo mais do que o palpável e apreensível, em que nos julgamos em casa. Mundo nunca é um objeto, que esta ante nós e que pode ser instituído. ${ }^{31}$
}

Talvez, Heidegger queira definir Mundo como a dimensão onde estão todas as coisas, uma dimensão na qual estamos e somos, onde tudo é e está. O lugar compreendido entre o pós-criação e o ante-morte. Mundo não é o objeto que vemos, mas tudo que está nele (idéia, sentido, expressão, impressão, matéria, forma, cor, significado, representação, 'inobjectual'). A definição de Mundo aqui é aberta, mas posiciona o Mundo na obra de arte. Mundo como a dimensão com ausência do Deus, e isso é o que mundifica o Mundo. A sobra ao ser um construir constante, ao estar em obra, entra na amplidão, que é o Mundo, pois a cada momento ela constrói, mostra, reconstrói, re-mostra. Acontece no mundo, num determinado espaço de tempo onde ela é e está. Isso é a abertura da obra, essa disponibilidade de existir a cada instante, ser uma a cada momento. E é dessa forma que o humano e a obra pertencem ao Mundo e são no Mundo.

O utensílio utiliza a matéria de que é feito para determinar sua serventia e utilidade. Esse material é consumido na fabricação e esvanece-se na serventia,

\footnotetext{
${ }^{30}$ Idem, op. cit., p. 33.

${ }^{31}$ Idem, op. cit., p. 35.

REVISTA DE ESTÉTICA E SEMIOTICA, BRASÍLIA, V. 2, N. 1 P. 1-15, JAN./JUN. 2012.
} 
desaparece. Assim, a matéria é mais adequada na medida em que não oferece resistência ao seu desaparecimento através da utilidade. Não se percebe o material porque se está muito ocupado com a utilização do produto que ele originou. Isso seria o desaparecimento do SER-utensílio do utensílio. Já a obra apresenta a matéria. Na obra a matéria é. Os materiais são mostrados como são, fazem parte dos objetos e são vistos não apenas como matéria, mas pelo que são. Estão num sistema, das artes, onde todos os elementos participam com um mesmo peso, onde nenhum desaparece e aparece em função de outro, onde todos fazem parte do SER-obra e estão ali, na abertura do Mundo.

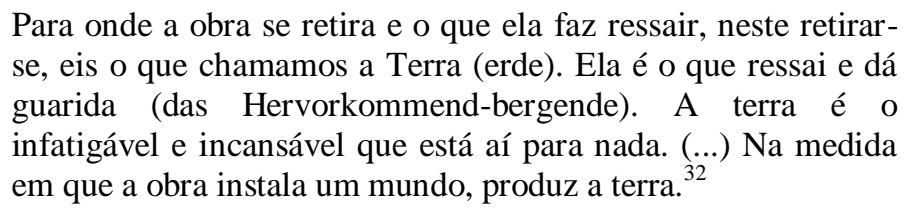

A Terra quer a matéria seja matéria, mas não só enquanto material, mas em quanto "designo", enquanto forma e expressão. A obra deixa a Terra ser terra, enquanto o mero utensílio consome a terra pelo seu uso. A produção da Terra é o que realiza a obra. O que Heidegger diz com o 'fechar da terra' é na verdade a possibilidade inesgotável que a matéria tem de formas e modos. A Terra torna a matéria verdadeiramente matéria na obra, não apenas enquanto material, mas enquanto meio para uma forma de expressão, comunicação, aberto do Mundo.

O Mundo existe a partir da Terra, do sistema de matérias com formas ali expostas. E a Terra só pode ser Terra no Mundo, dentro de um sistema. Mundo e Terra se relacionam entre si. Desse relacionamento incessante, tem-se um combate. Combate no sentido de que cada um eleva em si a auto-afirmação das suas essências. Nesse sentido, 'no combate, cada um leva o outro para além do seu SER próprio'. Esse combate une, e faz um sistema de ações e reações no qual a obra está em obra. Na medida em que a obra instaura um Mundo e produz uma Terra, ela gera e faz permanecer (enquanto for obra) esse combate.

A instituição de um mundo e a produção da terra constituem dois traços essenciais no SER-obra da obra. Elas pertencem uma a outra, porém, na unidade do SER-obra. Procuramos esta unidade quando meditamos no estar-em-si (insichstehen) da

\footnotetext{
${ }^{32}$ Idem, op. cit., p. 36.

REVISTA DE ESTÉTICA E SEMIOTICA, BRASÍLIA, V. 2, N. 1 P. 1-15, JAN./JUN. 2012.
} 
obra e tentamos dizer aquela certa quietação fechada do repousar em si. [...] Só o que se move pode repousar. ${ }^{33}$

A obra está num repouso de si mesma. Pela apreensão do acontecer do SER-obra percebemos por um momento, num repousar, a obra. Só no repousar da obra é que podemos perceber o que na obra está em obra. E o que está posto em obra na obra é a verdade. Esse repousar e o instante em que a obra está apreciada, o instante em que se apreende a verdade.

\section{A verdade}

Em Heidegger, a essência é aquilo que o ENTE é na verdade, e a procura é sobre a essência da verdade. E verdade é a desocultação do ENTE (para os gregos). "A essência verdadeira de uma coisa define-se a partir do seu verdadeiro, a partir da verdade do respectivo ENTE" ${ }^{34}$. O princípio da verdade desde a muito instaurada no passado seria a concordância do conhecimento com o seu objeto. Mas nesse sentido, temos a verdade apenas na desocultação do ENTE. Isso, em vista da tradução grega de verdade. E esse conceito apenas representa a justeza entre o conhecimento e a coisa, onde sempre haverá um pré-entendimento, ou determinação de algo. Entretanto, para Heidegger o que interessa em A Origem da Obra de Arte é a essência da verdade. É o pensar a verdade em primeiro. "Ora, precisamente não somos nós que pressupomos a desocultação do ENTE, mas é assim a desocultação do ENTE (SER) que nos determina numa essência tal que, na nossa representação, permanecemos inseridos, ficamos sempre a reboque da desocultação" ${ }^{\text {35 }}$. É essa desocultação do ENTE que determina a nós uma essência. E não o contrário, onde um conhecimento prévio ajusta-se a desocultacao. A desocultação é que nos leva ao ajuste do que é previamente conhecido. O ENTE existe antes de qualquer apreensão do homem sobre ele. Ele já está ali e se revela a nós através de sua desocultação, quando ele se abre pra clareira de nossa percepção.

O conceito de desocultação (entendimento e apreensão) do SER é colocado como um elemento essencial e existencial do qual não se pode apreender por completo. É o que se mostra sempre em partes, claro e escuro. Heidegger chega ao seu ponto principal, o entendimento do SER do ENTE como base e origem do que tudo possa ser.

\footnotetext{
${ }^{33}$ Idem, op. cit., p. 38.

${ }^{34}$ Idem, op. cit., p. 40.

${ }^{35}$ Idem, op. cit., p. 41.

REVISTA DE ESTÉTICA E SEMIOTICA, BRASÍLIA, V. 2, N. 1 P. 1-15, JAN./JUN. 2012.
} 


\begin{abstract}
As coisas são, os homens, os dons e a oferta são, o animal e a planta são, o utensílio e a obra são. O ENTE está no SER. Através do SER perpassa uma fatalidade velada, suspensa entre o divino e o antidivino. O homem é impotente para dominar uma larga parte do que há no SER. Só pouco é conhecido. O conhecido permanece algo de aproximado, o dominado algo de incerto. Nunca o ENTE, como poderia demasiado facilmente parecer, esta debaixo do nosso poder ou até na nossa representação. Se meditarmos isto tudo conjuntamente, então apreendemos, parece, tudo o que de algum modo é, ainda que o apreendemos de um modo bastante grosseiro. [...] E todavia: para além do ENTE, mas não longe dele, mas sim a partir dele, acontece ainda algo de diferente. No seio do ENTE, na sua totalidade advém um lugar aberto. Há uma clareira. Pensada a partir do ENTE, ela tem mais SER do que o ENTE. Este meio aberto não é envolvido pelo ENTE, mas é antes o próprio meio coruscante que engloba como nada, que mal conhecemos, todo o ENTE. ${ }^{36}$
\end{abstract}

Nesse sentido, o ENTE vem como a coisa a qual apreendemos, o momento do conhecer, do apreender, da verdade que se mostra. O SER do ENTE significa que só há conhecimento do SER, pelo ENTE. É o ENTE que se apresenta, que se desvela, que aparece, que vem ao claro.

O ENTE como ENTE só pode SER, quando assoma e advém no clareado desta clareira. Só esta clareira confere e garante a nós, homens, um acesso em direção ao ENTE, que nós próprios somos. [...] O ENTE só pode ser oculto no espaço de jogo do clareado. Todo o ENTE que vem ao nosso encontro e que nos acompanha mantém esta estranha oposição da presença, na medida em que ao mesmo tempo se retém sempre numa ocultação. A clareira em que este ENTE assoma e em si simultaneamente ocultação. Mas ocultação reina no seio do ENTE de modo duplo. ${ }^{37}$

“A desocultação (verdade) do ENTE nunca é um estado que esta aí, mas sempre um acontecimento" ${ }^{38}$. Heidegger coloca o jogo do desvelamento, do claro e do escuro como um eclipse. Um vela o outro a cada momento, e isso faz com que o ENTE apareça de fato, no seu sim e não, no diferente que é. Heidegger toma cuidado pra não delimitar e não definir numa totalidade o que os termos são. Tudo é um ACONTECIMENTO. Tudo esta ali e é apreendido num determinado momento, e a apreensão nunca é do todo, mas da parte que quer e/ou esta a mostra, no claro e que aos poucos se movimenta e já esta em outro lugar, e outra parte, agora, se mostra. Ressalta-se que isso não ocorre num

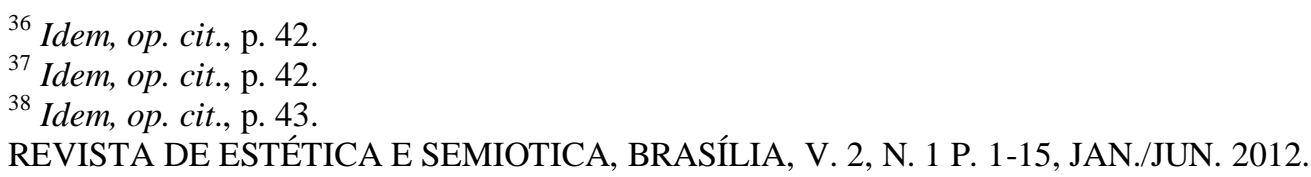




\section{ANA CATHARINA MARQUES}

ciclo finito, no qual a observação num determinado momento nos levasse a total apreensão da coisa. Não, a forma e ritmo como isso acontece não é determinada, as interferências da coisa com o mundo, como o outro é que formam essa claridade e esse escuro, esse desvelamento e esse velamento. É a relação momentânea da coisa com o homem é o desenho do que é. Essa abertura de Heidegger sobre as definições das coisas é essencial para compreender como o conhecimento sobre o SER e sobre a obra de arte se forma. De como a verdade encontra-se numa definição aberta, guiada por percepções e experiências. Por isso ele sempre questiona a essência da verdade ao invés da verdade. Para ele a questão é sobre a origem.

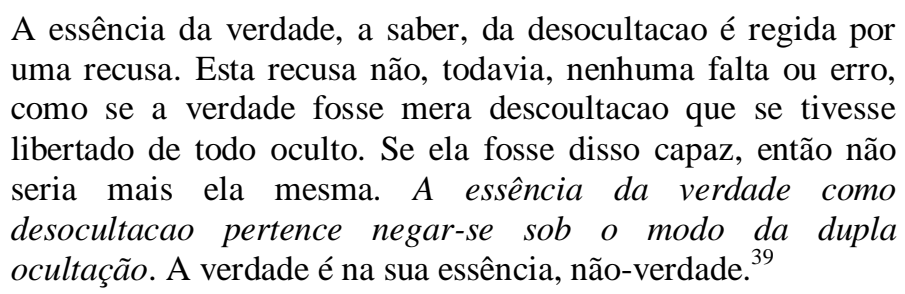

Isso não coloca a essência da verdade como falsidade. Assim, se vê que a verdade é sempre representada dialeticamente também pelo seu contrário. Agora, Heidegger une as definições ao dizer que nesse aberto na qual encontramos a essência da verdade pertencem também Mundo e Terra. Mundo (onde estão todas as decisões) e Terra onde presentificam a essência da verdade ao serem o combate originário da clareira e ocultação. "(A verdade) Acontece em raros modos essenciais. Um dos modos como a verdade acontece é o SER-obra da obra. Ao instituir um mundo e ao produzir a terra, a obra é o travar desse combate no qual se disputa a desocultacao do ENTE na sua totalidade, a verdade" ${ }^{, 40}$. A verdade acontece no Estar-aí-de-pé (dastehen). Na obra, o que é obra esta em aberto, esta a todo momento num desocultar-se. E quanto mais simples e essencial a obra for, mais o ENTE se torna mais ENTE. "Desta forma, o SER que se oculta clareia-se. O clareado desta natureza na obra é o belo. A beleza e um modo como a verdade enquanto desocultacao advêm"41.

O artista não domina o SER da obra por inteiro. Depois de pronta, a obra é e está a cada momento num desvelar constante, além do que o artista tenha imaginado. Assim como acontece com o domínio do nosso SER, que não existe. O artista tem sua

\footnotetext{
${ }^{39}$ Idem, op. cit., p. 43.

${ }^{40}$ Idem, op. cit., p. 44.

${ }^{41}$ Idem, op. cit., p. 44.

REVISTA DE ESTÉTICA E SEMIOTICA, BRASÍLIA, V. 2, N. 1 P. 1-15, JAN./JUN. 2012.
} 
grandeza pela escolha, pelo partido que ele adota na produção, realização da obra. Entretanto, após sua finalização, a obra é a própria obra. Ela é em si mesma ela mesma e a todo tempo está em obra. Por isso não há um domínio de sua apreensão.

Heidegger libera a leitura da imagem da obra, deixa-a livre para que os elementos surjam através do que se possa ser apreendido. Aos poucos eles vão revelando, em composição entre si, o mundo da obra de arte. A vontade de poder é o domínio da existência, do entendimento da existência. E para algo de si tem q ter em si a contradição. Aqui a contradição esta presente na tentativa do domínio da vida humana, a vontade de sentir-se capaz de dominar a própria existência, a qual, não pode ser dominada, por ser finita. Ve-se que o reconhecer a obra é um processo que sempre dialoga com o sujeito, com o ser apreciador, ela só se realiza na presença do mesmo.

\section{REFERÊNCIAS}

HEIDEGGER, Martin. A Origem da Obra de Arte. Tradução: Maria da Conceição Costa. Lisboa, Portugal: Edições 70, Ltda. 2005.

NOTAS DE AULA: Arte e arquitetura. Prof. Flavio Kothe. PPG/FAU-UnB. Brasília, $1 / 2011$. 